\title{
ANALISIS INDUSTRI FILET PATIN INDONESIA DENGAN MODEL BERLIAN PORTER
}

\author{
Indonesian Pangasius Fillet Industries Analysis of Porter's Diamond Model \\ Oleh : \\ Suhendra ${ }^{1}$, Arif Satria ${ }^{2}$, Budhi Hascaryo Iskandar ${ }^{3}$ \\ ${ }^{1}$ Mahasiswa Sekolah Bisnis, Institut Pertanian Bogor \\ ${ }^{2}$ Staf Pengajar Jurusan Ekologi Manusia, Institut Pertanian Bogor \\ ${ }^{3}$ Staf Pengajar Program Studi Teknologi Perikanan Laut \\ *Korespondensi: hendramgr@gmail.com
}

\begin{abstract}
ABSTRAK
Ikan patin merupakan komoditas perikanan yang memiliki pangsa pasar sangat besar baik didalam negeri maupun diluar negeri. Ikan patin yang diolah menjadi filet diminati pasar Amerika dan Eropa terutama yang berdaging putih. Penelitian ini menggunakan metode deskriptif kualitatifdengan teknik purposive sampling. Responden ahli terkait dengan industri filet patin yaitu responden dari Direktorat Pemasaran Ditjen Penguatan Daya Saing Kementerian Kelautan dan Perikanan, Direktorat Pengolahan dan Bina Mutu Ditjen Penguatan Daya Saing Kementerian Kelautan dan Perikanan, Asosiasi Pengusaha Pengolahan \& Pemasaran Produk Perikanan Indonesia, Asosiasi Pengusaha Catfish Indonesia dan CV. Karunia Mitra Makmur.

Analisis dan pengolahan data kondisi industri filet patin Indonesia dilakukan dengan Model Berlian Porter. Berdasarkan hasil analisis Model Berlian Porterdiperoleh untuk Faktor Kondisi 3,2; Kondisi permintaan, dan pertumbuhan 2,4; industri terkait dan industri pendukung 2,8; struktur pasar dan strategi perusahaan 2,8; Peran Pemerintah 3,6 dan Faktor peran 3,7. Hal ini menunjukan bahwa kondisi permintaan dan pertumbuhan, industri terkait dan industri pendukung serta struktur pasar dan stretegi perusahaan industri filet patin Indonesia dalam kategori rendah, Sementara faktor kondisi input, peran pemerintah dan faktor kontribusi dalam kategori sedang.
\end{abstract}

Kata Kunci : Model Berlian Porter, industri filet patin, purposive sampling.

\begin{abstract}
Pangasius is a fishery commodity that has a very large market share both domestically and abroad. Pangasius are processed into filet preferred American and European markets, especially the white flesh. This study used descriptive qualitative method and purposive sampling. Respondents expert related pangasius filet industry that respondents from the Directorate of Marketing DG Strengthening the Competitiveness of the Ministry of Marine Affairs and Fisheries, Directorate of Processing and Development Quality DG Strengthening Competitiveness of the Ministry of Marine Affairs and Fisheries, Fisheries Processing \& Marketing Association of Indonesian Fishery Products, Association of Indonesian Catfish Entrepreneurs and CV. Karunia Mitra Makmur.

Diamonds Porter's Model used to Analysis of Indonesian pangasius filet industri.Based on the results of Diamonds Porter's Model for the Condition Factor 3.2; Conditions of demand and growth 2.4; Related industries and supporting industries 2.8; Market structure and corporate strategy 2.8; Government Role 3.6 and Chance Factor 3.7. This indicates that the condition of demand and growth, related industries and supporting industries market structure and corporate strategy of Indonesian pangasius filet industry are in low category, while input condition factor, government role and contribution factor in medium category.
\end{abstract}


Keywords: Diamond Porter's Model, pangasiuss filet industry, purposive sampling.

\section{PENDAHULUAN}

Indonesia dengan luas wilayah perairan $70 \%$ memilik potensi yang sangat besar untuk bisa berdaya saing disektor perikanan. Sektor perikanan budidaya terus digalakan dalam upaya peningkatan kualitas maupun kuantitas produksi perikanan budidaya. Keseriusan pemerintah dalam mengembangkan sektor perikanan budidaya terlihat pada Renstra Perikanan Budidaya 2010-2014 dengan melakukan arah kebijakan strategi dimana salah satu langkah yang diambil adalah dengan mengembangkan komoditas unggulan sektor perikanan budidaya.

Komoditas budidaya unggulan tersebut adalah: (1) udang; (2) rumput laut; (3) nila; (4) lele; (5) patin; (6) gurame; (7) kerapu; (8) kakap; (9) bandeng; dan (10) ikan lainnya. Disamping sepuluh komoditas unggulan tersebut, pengembangan komoditas lainnya yang potensial dan spesifik daerah tetap dikembangkan baik dalam rangka meningkatkan penerimaan devisa negara, pemenuhan konsumsi di dalam negeri, peningkatan pendapatanmasyarakat, maupun untuk pelestarian jenis-jenis ikan lokal yang cenderung akan mengalami kepunahan.

Produksi patin nasional menunjukan tren yang meningkat dan sejak tahun 2011 - 2014 tercatat mengalami kenaikan rata-rata sebesar 25\%. Tahun 2014 sebesar 418.002 ton atau naik sebesar $2 \%$ dibandingkan tahun 2013 sebesar 410.883ton dan mengalami penurunan pada tahun 2015 yaitu menjadi 256.287 ton. Produksi patin nasional belum dapat bersaing dengan Vietnam dimana produksinya mencapai 1 juta ton pertahun sehingga Vietnam telah menjadi produsen utama dan membanjiri pasar dunia termasuk Indonesia.

Tahun 2011 pasar domestik mampu menyerap 400 tonfilet patinper bulan, setara dengan 1.200 ton ikan patin utuh namun 90\% merupakan impor dari Vietnam (KKP 2015; SEAFDEC 2014). Pada tahun 2011 keluar Permen KP No. 15 yang melarang impor produk filet patin (dory) yang diharapkan dapat merangsang tumbuhnya usaha filet patin didalam negeri

Tujuan penelitian ini adalah untuk melihat kondisi industri filet patin dalam negeri dengan melihat faktor yang berkaitan langsung seperti kondisi input, kondisi permintaan, industry pendukung, struktur pasar dan strategi perusahaan serta faktor yang tidak terkait langsung seperti peran pemerintah dan faktor kesempatan.

Berdasarkan penelitian yang dilakukan oleh Ramadhan et al. (2016), menganalisis mengenai strategi daya saing filet patin Indonesia. Penelitian tersebut menguraikan beberapa kondisi kekuatan internal industri filet patin Indonesia seperti: tersedianya lokasi produksi yang luas dengan potensi yang belum dimanfaatkan seluas 2.964.331 hektar tambak dan 156.561 hektar perairan umum (KKP 2015), produksi ikan patin yang tinggi sebesar 410.883 ton pada tahun 2013 (KKP 2014), ketersediaan sumberdaya manusia (104 KUB budidaya sebesar 1.150 jumlah anggota) dan dukungan pemerintah. Kondisi kelemahan internal seperti rendahnya daya saing bahan baku lokal, kurangnya standar aplikasi fillet patin Indonesia, biaya produksi bahan baku tinggi dan infrastruktur yang belum memadai. Penelitian ini juga menguraikan peluang eksternal seperti permintaan yang besar pada industri horeka lokal yang mencapai 600 ton dan potensi konsumen dalam negeri (kenaikan proyeksi tingkat konsumsi perikanan hingga $54,19 \mathrm{~kg} / \mathrm{kapok} /$ tahun pada 2019). Selain itu ancaman faktor eskternal seperti persaingan dengan produk impor Vietnam dan tingkat inflasi.

Penelitian lain yang dilakukan oleh Suryaningrum (2008) mengenai "Ikan Patin: Peluang Ekspor, Penanganan Pascapanen, Dan Diversifikasi Produk Olahannya" menemukan bahwa peran strategis pemerintah (pusat maupun daerah), lembaga riset, swasta, serta perbankan diharapkan dapat meningkatkan tumbuhnya industri budidaya ikan patin yang selama ini belum dioptimalkan. Pengembangan budidaya ikan patin dengan sistem sentra yang merupakan pusat kegiatan budidaya di 
satu kawasan/lokasi tertentu yang menggunakan bibit, teknologi, sarana yang sama, serta menghasilkan produk yang sejenis perlu digalakkan.

\section{METODE PENELITIAN}

Penelitian ini menggunakan data primer yang dikumpulkan melalui wawancara dan kuesioner terstruktur. Kuesioner berisi pertanyaan tertutup untuk memberikan tanggapan yang lebih terstruktur sehingga dapat memfasilitasi rekomendasi yang nyata. Wawancara memberi informasi tambahan yang tidak ditangkap dalam pertanyaan tertutup.

Pengambilan sampel digunakan metode purposive sampling dimana responden yang dilibatkan dalam penelitian ini merupakan pakar dalam industri filet patin. Responden pakar yang dilibatkan dalam penelitian ini terdiri dari Direktorat Pemasaran Ditjen PSDKP KKP, Direktorat Pengolahan dan Bina Mutu Ditjen PSDKP KKP, Asosiasi Pengusahan Pengolahan dan Pemasaran Produk Perikanan Indonesia (AP5I), Asosiasi Pengusaha Catfish Indonesia (APCI) dan CV. Karunia Mitra Makmur.

Responden diberikan beberapa pertanyaan mengenai kondisi industry patin kemudian diberikan pilihan jawaban kualitatif. Jawaban kualitatif tersebut kemudian dikonversi ke dalam nilai dengan skala 1-5 dimana 1 bernilai sangat rendah, 2 bernilai rendah, 3 bernilai sedang, 4 bernilai tinggi dan 5 bernilai sangat tinggi atau pernyataan lainnya yang setara. Data kuantitatif dianalisis dengan menggunakan statistik deskriptif seperti persentase, skor rata-rata dan standar deviasi sehingga memudahkan dan memungkinkan perbandingan melalui penggunaan metode statistik untuk ilmu sosial.

\section{HASIL DAN PEMBAHASAN}

Industri filet ikan patin di pasar ASEAN didominasi oleh negara Vietnam sebagai penghasil terbesar produksi ikan patin. Data dari Fishery Statistical Bulletin of Southeast Asia menunjukan tahun 2014 produksi ikan patin Vietnam mencapai 1,1 Juta ton. Sementara negara-negera ASEAN lainnya tercatat Indonesia denganproduksi ikan patin 418.002 ton pada tahun 2014. Dengan kapasitas produksi yang besar, Vietnam mendominasi pasar filet patin di ASEAN. Nilai ekspor patin Vietnam ke ASEAN pada tahun 2016 mencapai 62.35 juta US\$. Ekspor patin Vietnam ke negara-negara ASEAN yang terbesar adalah Thailand sebesar 36\% kemudian Singapura 25 \%, Filipina 21\% Malaysia, 17\% dan pasar lainnya 1\% (Natalia et al. 2012).

Produksi komoditas ikan patin Indonesia antara tahun 2010-2015 tercatat mengalami peningkatan setiap tahunnya namun menurun pada tahun 2015. Dengan potensi perairan budidaya ikan patin, Indonesia hanya memproduksi dikisaran 400 ton dimana jumlah itu sangat jauh dengan produksi ikan patin yang dihasilkan Vietnam. Provinsi penghasil komoditas ikan patin terbesar di Indonesia adalah Sumatera Selatan dengan produksi mencapai 200 ton pertahun. Kemudian beberapa provinsi seperti Kalimantan Selatan,Kalimantan Tengah, Riau, Jambi, Jawa Barat, Lampung, Sumatera Barat, Jawa Timur dan Kalimantan Timur merupakan penyumbang produksi patin di Indonesia.

Serapan pasar dalam negeri terbesar dalam bentuk ikan patin segar sekitar $80 \%$, sisanya dalam bentuk filet, patin asap serta olahan lainnya. Tahun 2011 konsumsi filet patin dalam negeri mencapai 400 ton namun sekitar 90\% dipenuhi oleh filet patin impor dari Vietnam (KKP 2015). Dengan kondisi tersebut pemerintah melakukan upaya membatasi impor filet patin dari Vietnam dalam rangka meningkatkan industri filet patin dalam negeri. Tahun 2017 diperkirakan konsumsi filet patin dalam negeri sekitar 600-700 ton. Produksi filet patin dalam negeri dihasilkan dari beberapa perusahaan seperti Tabel I: 
Tabel 1 Perusahaan Pengolahan Filet Patin di Indonesia

\begin{tabular}{|c|c|c|c|c|}
\hline No & Nama Perusahaan & Lokasi & Jenis Olahan & $\begin{array}{l}\text { KapasitasProduksi } \\
\text { (ton/Bulan) }\end{array}$ \\
\hline 1 & $\begin{array}{l}\text { PT .Centra Pangan } \\
\text { Pertiwi }\end{array}$ & $\begin{array}{l}\text { Sidoarjo, Jakarta, } \\
\text { Lampung }\end{array}$ & $\begin{array}{l}\text { Filet Ikan Beku, } \\
\text { Steak Patin }\end{array}$ & $200-250$ \\
\hline 2 & PT .ExpavetNasuba & Medan, Sumatera Utara & Filet Ikan Beku & $150-200$ \\
\hline 3 & $\begin{array}{l}\text { CV. Karunia Mitra } \\
\text { Makmur }\end{array}$ & Purwakarta, Jawa Barat & Filet Ikan Beku & $75-50$ \\
\hline 4 & PT. Adib Global Food & Karawang, Jawa Barat & Filet Ikan Beku & $75-50$ \\
\hline 5 & PT. Kelola Mina Laut & Gresik, Jawa Timur & Filet Ikan Beku & $10-15$ \\
\hline 6 & PT. Delta Mina Perkasa & $\begin{array}{l}\text { Tulungagung, Jawa } \\
\text { Timur }\end{array}$ & Filet Ikan Beku & $25-40$ \\
\hline 7 & $\begin{array}{l}\text { PT. Marindo Makmur } \\
\text { Usaha Jaya }\end{array}$ & Surabaya, Jawa Timur & Filet Ikan Beku & $5-10$ \\
\hline 8 & $\begin{array}{l}\text { PT. Samudra Kencana } \\
\text { Mina }\end{array}$ & Sidoarjo, Jawa Timur & Filet Ikan Beku & $5-10$ \\
\hline
\end{tabular}

Sumber: KKP (2015)

\section{Faktor-Faktor yang berkontribusi terhadap daya saing industri filet patin Indonesia}

Tabel 2 menunjukkan ringkasan penelitian mengenai faktor kontribusi spesifik terhadap keberhasilan industri filet patin. Faktor yang paling berkontribusi terhadap industri filet patin sangat dikaitkan dengan biaya produksi yang rendah (listrik, tenaga kerja, transport) dengan skor rata-rata 3,60 dan kebijakan pemerintah terhadap iklim industri yang kondusif 3,60. Stabilitas politik, akses terhadap bahan baku, akses ke pasar, kedekatan dengan perusahaan lain dan kepadatan penduduk berkontribusi terhadap keberhasilan perusahaan mencapai tingkat moderat yang digambarkan dengan skor rata-rata masing-masing 3,00; 3,20;3,20;3,00 dan 2,00. Penyimpangan standar yang relatif rendah mengindikasikan bahwa sebagian besar responden sepakat. Hasil analisis menunjukkan bahwa nilai faktor kepadatan penduduk yang rendah menjelaskan faktor tersebut tidak menentukan kontribusi yang signifikan terhadap industri filet patin. Faktorseperti stabilitas politik berkontribusi terhadap industri tersebut sampai tingkat yang moderat yang dapat dijelaskan bahwastabilitas politik membuat dunia usaha industri filet patin bisa berdaya saing. Akses terhadap pasar dan bahan baku merupakan faktor-faktor yang berperan penting dengan tetap melihat biaya produksi yang lebih rendah.

Tabel 2 Faktor-Faktor yang berkontribusi terhadap daya saing industri filet patin Indonesia

\begin{tabular}{lcc}
\hline \multicolumn{1}{c}{ Atribut } & Mean & STDev \\
\hline Biaya produksi rendah (listrik, tenaga kerja, transport) & 4,40 & 0,55 \\
Kebijakan pemerintah terhadap iklim industri yang kondusif & 4,60 & 0,55 \\
Stabilitas politik & 3,60 & 0,55 \\
Akses terhadap pasar & 4,20 & 1,10 \\
Akses terhadap bahan baku & 4,00 & 1,00 \\
Kedekatan dengan perusahaan lain & 4,00 & 0,71 \\
Kepadatan penduduk & 2,80 & 0,84 \\
\hline Sumber: Data Penelitian (2017) & &
\end{tabular}

\section{Pertumbuhan dan kondisi daya saing industri filet ikan patin Indonesia di Pasar ASEAN}

Tabel 3 menunjukkan analisis mengenai sejauh mana pertumbuhan dan daya saing industri filet patin Indonesia di pasar ASEAN. Hasil pengolahan data memperlihatkan bahwa 20\% responden 
berpendapat bahwa pertumbuhan industri filet ikan patin Indonesia masih rendah, $40 \%$ menyatakan pertumbuhan industri filet patin sedang, sementara $20 \%$ berpendapat bahwa pertumbuhannya tinggi. Data tersebut menunjukkan bahwa pada umumnya responden mengindikasikan pertumbuhan industri filet ikan patin Indonesia masih sedang. Kondisi daya saing industri filet ikan patin Indonesia di pasar ASEAN dengan melihat data hasil analisis menunjukan bahwa sekitar $20 \%$ responden menyatakan sangat rendah sementara $60 \%$ responden menyatakan masih rendah. Hal ini bisa terlihat dari peran ekspor filet patin Indonesia yang hampir tidak ada dipasar ASEAN. Dengan melihat data yang ada kondisi industri filet ikan patin Indonesia masih berdaya saing rendah. Pembobotan rata-rata dilakukan untuk mengetahui nilai secara umum untuk kondisi pertumbuhan Industri filet patin dalam negeri dan daya saing di pasar ASEAN.Hasil pembobotan rata-rata untuk skor pertumbuhan filet patin dalam negeri adalah 2,8 menunjukan bahwa pertumbuhan filet patin dalam negeri masih cenderung rendah mendekati sedang. begitu pula dengan daya saing industri filet patin dalam negeri dengan skor 2,0 menunjukan bahwa daya saing industri filet patin dalam negeri masih rendah di pasar ASEAN.

Tabel 3 Kondisi pertumbuhan dan daya saing industri filet ikan patin Indonesia dipasar ASEAN

\begin{tabular}{lcccccc}
\hline \multirow{2}{*}{ Kondisi } & \multicolumn{2}{c}{$\begin{array}{c}\text { Pertumbuhan Industri } \\
\text { Filet Patin Dalam Negeri }\end{array}$} & \multicolumn{2}{c}{ Tingkat Daya Saing Industri } \\
& Frekuensilet Patin di pasar ASEAN \\
\hline & 0 & 0 & 0 & 1 & $20 \%$ & 0,2 \\
Sangat Rendah & 2 & $40 \%$ & 0,8 & 3 & $60 \%$ & 1,2 \\
Rendah & 2 & $40 \%$ & 1,2 & 1 & $20 \%$ & 0,6 \\
Sedang & 1 & $20 \%$ & 0,8 & 0 & $0 \%$ & 0 \\
Tinggi & 0 & $0 \%$ & 0 & 0 & $0 \%$ & 0 \\
Sangat Tinggi & & & 2,8 & & & 2 \\
Jumlah Pembootan Rata-rata & & & & & &
\end{tabular}

Sumber : Data Penelitian (2017)

\section{Peningkatan daya saing industri filet ikan patin Indonesia dalam Pasar ASEAN}

Tabel 4 menunjukkan upaya yang dilakukan oleh industri filet patin Indonesia dalam rangka meningkatkan daya saing di pasar ASEAN. Menurut data tersebut, penerapan praktek Good Manufacturing Proces (GMP) telah dilakukan Industri filet patin Indonesia dengan skor 3,00. Standar deviasi yang rendah memperlihatkan bahwa responden sepakat dengan kondisi tersebut. Peningkatan mutu sumberdaya manusia, peningkatan infrastruktur teknologi pengolahan, peningkatan infrastrktur teknologi informasi perusahaandan peningkatan investasi dan modal perusahaan dengan masing-masing skor 2,4; 2,4; 2,0 dan 2,4menunjukan bawah peningkatan untuk aspek-aspek diatas belum dilakukan.

Tabel 4 Peningkatan daya saing Industri filet ikan patin Indonesia di pasar ASEAN

\begin{tabular}{lrc}
\hline \multicolumn{1}{c}{ Atribut } & Mean & STDev \\
\hline Peningkatan Mutu Sumberdaya Manusia & 3,00 & 0,000 \\
Peningkatan Infrastruktur Teknologi Pengolahan & 3,00 & 0,000 \\
eningkatan Infrastruktur Teknologi Informasi Perusahaan & 2,40 & 0,548 \\
Peningkatan Investasi dan Modal Perusahaan & 2,80 & 0,447 \\
Penerapan praktek Good Manufacturing Proses (GMP) & 3,60 & 0,548 \\
\hline Sumber: Data Penelitian (2017) & &
\end{tabular}

Sumber : Data Penelitian (2017) 


\section{Kondisi Industri Filet Patin Indonesia dengan Model Berlian Porter}

\section{Kondisi Permintaan}

Perusahaan yang menghadapi permintaan domestik yang tinggi cenderung menjual produk unggulan karena pasar menuntut kualitas tinggi dan kedekatan dengan konsumen tersebut memungkinkan perusahaan untuk lebih memahami kebutuhan pelanggan namun dalam kasus industri filet patin menunjukan bahwa konsumi terhadap komoditas ini belum sebesar produk-produk perikanan lainnya seperti ikan lele, udang dan sebagainya. Sebanyak 20\% Responden menilai kondisi permintaan filet ikan patin dalam negeri masih rendah sementara $60 \%$ responden menyatakan sedang. Sebanyak $40 \%$ responden menyatakan bahwa pertumbuhan atau peningkatan terhadap permintaan filet ikan patin dalam negeri masih terhitung rendah dan $40 \%$ menyatakan sedang. Hal ini bisa dilihat dari jumlah pengolahan filet ikan patin terhadap produksi ikan patin segar hanya sekitar 20\% nya. Bagaimana kondisi permintaan filet ikan patin Indonesia di ASEAN, dari hasil penelitian menunjukan bahwan 20\% responden menyatakan tidak ada permintaan filet patin dari pasar ASEAN, 40\% responden menyatakan rendah dan $20 \%$ responden menyatakan sedang. Adanya permintaan filet patin dari pasar luar negeri walaupun sangat kecil dimana transaki ekspor untuk produk filet patin masih tergabung dengan komoditas lain sehingga jumlah angka pastinya tidak terlihat. Pertumbuhan atau peningkatan permintaan filet patin Indonesia konsisten dengan kondisi permintaannya.

Tabel 5 Kondisi permintaan

\begin{tabular}{|c|c|c|c|c|c|c|c|c|c|c|c|c|}
\hline \multirow[t]{2}{*}{ Kondisi } & \multicolumn{3}{|c|}{$\begin{array}{l}\text { Permintaan Filet Ikan } \\
\text { Patin dalam negeri }\end{array}$} & \multicolumn{3}{|c|}{$\begin{array}{l}\text { Pertumbuhan / } \\
\text { peningkatan } \\
\text { permintaan filet } \\
\text { patin dalam negeri }\end{array}$} & \multicolumn{3}{|c|}{$\begin{array}{l}\text { Permintaan filet patin } \\
\text { luar negeri khususnya } \\
\text { di ASEAN }\end{array}$} & \multicolumn{3}{|c|}{$\begin{array}{c}\text { Pertumbuhan / } \\
\text { peningkatan } \\
\text { permintaan filet } \\
\text { patin luar negeri } \\
\text { khususnya di ASEAN }\end{array}$} \\
\hline & Frekuer & resentase & Bobot & Frekuens & Presentas & Bobot & Frekue & siPresentase & Bobot & Frekue & Presentas & Bobot \\
\hline $\begin{array}{l}\text { Tidak } \\
\text { ada }\end{array}$ & 0 & $0 \%$ & 0 & 0 & $0 \%$ & 0 & 2 & $40 \%$ & 0,4 & 2 & $40 \%$ & 0,4 \\
\hline Rendah & 1 & $20 \%$ & 0,4 & 2 & $40 \%$ & 0,8 & 2 & $40 \%$ & 0,8 & 2 & $40 \%$ & 0,8 \\
\hline Sedang & 3 & $60 \%$ & 1,8 & 3 & $60 \%$ & 1,8 & 1 & $20 \%$ & 0,6 & 1 & $20 \%$ & 0,6 \\
\hline Tinggi & 1 & $20 \%$ & 0,8 & 0 & $0 \%$ & 0 & 0 & $0 \%$ & 0 & 0 & $0 \%$ & 0 \\
\hline $\begin{array}{l}\text { Sangat } \\
\text { Tinggi }\end{array}$ & 0 & $0 \%$ & 0 & 0 & $0 \%$ & 0 & 0 & $0 \%$ & 0 & 0 & $0 \%$ & 0 \\
\hline Jumlah t & bot rat & & 3 & & & 2,6 & & & 1,8 & & & 1,8 \\
\hline
\end{tabular}

Pembobotan rata-rata terhadap Tabel 5, diketahui untuk permintaan filet patin dalam negeri memiliki skor 3,0 hal ini menunjukan bahwa kondisi permintaan filet patin dalam negeri relatif sedang. Sedangkan untuk pertumbuhan permintaan filet patin dalam negeri dengan skor 2,8 menunjukan bahwa pertumbuhan permintaan filet patin dalam negeri masih cenderung rendah mendekati sedang. Pembobotan rata-rata untuk permintaan filet patin di pasar ASEAN serta pertumbuhan permintaan dengan skor 1,8 menujukan bahwa permintaan filet patin Indonesia di pasar ASEAN masih rendah begitu pula dengan pertumbuhan permintaannya.

2. Kondisi Faktor

a. Faktor Input

Kondisi faktor mengacu pada input yang digunakan sebagai faktor produksi seperti tenaga kerja, bahan baku, permodalan, listrik, air, tenaga kerja, cold storage serta jaringan transportasi. penetapan ketersediaan faktor kondisi industri filet patin berdasarkan berbagai masukan yang diperoleh dari wawancara responden dengan menetapkan bahan baku, modal dan investasi, listri, air, tenaga kerja, cold storage serta jaringan transportasi dan sejauh mana faktor-faktor 
tersebut berperan dalam industri filet patin. Tabel 6 Terlihat bahwa kondisi faktot input untuk air dan transportasi dengan skor 4,20 dan 4,00 menunjukan bahwa kedua tabel di bawah menunjukkan hasil dari kodisi faktor tersebut sangat tersedia bagi industri filet patin. Sedangkan, untuk cold storage, listrik, tenaga kerja, modal dan investasi serta bahan baku patin relatif cukup tersedia bagi industri filet patin dengan skor berturut-turut 3,80;3,80;3,60;3,20; 3,00 .

Tabel 6 Kondisi input

\begin{tabular}{|c|c|c|}
\hline Atribut & Mean & STDev \\
\hline Bahan Baku ikan Patin & 3,00 & 0,000 \\
\hline Modal dan investasi & 3,20 & 0,447 \\
\hline Listrik & 3,80 & 0,447 \\
\hline Air & 4,20 & 0,447 \\
\hline Tenaga kerja/mesin filet & 3,60 & 0,548 \\
\hline Cold Storage & 3,80 & 0,447 \\
\hline Transportasi & 4,00 & 0,000 \\
\hline
\end{tabular}

Sumber: Data penelitian (2017)

b. Biaya Input

Tabel 7 menunjukkan kondisi mengenai penetapan harga input dari faktor kondisi yang telah ditetapkan sebelumnya. Hasil pengolahan data menunjukan bahwa biaya input terhadap industri filet patin yang meliputi biaya bahan baku, modal dan investasi, listri, air, tenaga kerja, cold storage serta jaringan transportasi cukup murah dengan skor dikisaran 3,60 - 3,80. Penyimpangan standar relatif rendah yang mengindikasikan bahwa sebagian besar responden sepakat dengan kondisi tersebut. Hasil tersebut menunjukan bahwa biaya kondisi faktor masih cukup terjangkau sehingga bisa memberikan keunggulan kompetitif pada industri filet patin dalam negeri.

Tabel 7 Biaya input

\begin{tabular}{lcc}
\hline \multicolumn{1}{c}{ Atribut } & Mean & STDev \\
\hline Bahan Baku ikan Patin & 3,60 & 0,548 \\
Modal dan investasi & 3,80 & 0,447 \\
Listrik & 3,60 & 0,548 \\
Air & 3,60 & 0,548 \\
Tenaga kerja/ mesin filet & 3,80 & 0,447 \\
Cold Storage & 3,60 & 0,548 \\
Transportasi & 3,80 & 0,447 \\
\hline
\end{tabular}

c. Permodalan

Kondisi permodalan menunjukan bahwa sejauh manasektor pembiayaan dalam mendukung industri filet patin. hasil analisis data menunjukan bahwa bunga untuk modal atau pinjaman relatif tinggi dengan skor 3,80 sementara kondisi permodalan dengan indikator daya tawar pemilik modal/pemberi modal menunjukan skor 3,20 yang berarti bahwa pemodal memegang kendali atas keputusannya terhadap penempatan modal untuk indutstri filet patin. atribut kondisi permodalan yang merangsang industri filet patin dan kemudahan mendapatkan modal/pinjaman menunjukan skor yang rendah 2,20 dan 2,60 menunjukan bahwa faktor permodalan kurang mendukung keberadaan industri filet patin. 
Tabel 8 Kondisi permodalan

\begin{tabular}{lcc}
\hline \multicolumn{1}{c}{ Atribut } & Mean & STDev \\
\hline Merangsang industri filet patin dalam negeri & 2,20 & 0,837 \\
Mudah mendapatkan Modal / Pinjaman & 2,60 & 0,548 \\
Bunga Modal /Pinjaman & 3,80 & 0,447 \\
Daya tawar pemilik/pemberi modal & 3,20 & 0,837 \\
\hline
\end{tabular}

Sumber: Data penelitian (2017)

\section{Karakteristik tenaga kerja pada industri filet patin Indonesia}

Hasil pengolahan data mengenai karakteristik tenaga kerja dalam industri filet patin menunjukan bahwa tingkat pendidikan, keterampilan/pelatihan dan daya tawar tenaga kerja dalam indutri filet patin masih rendah yang ditunjukan dengan skor masing-masing, 2,60;2,40;2,40 sementara untuk upah dan gaji serta ketersediaan tenaga kerja terindikasi sedang dengan skor 3,00.

Tabel 9 Karakteristik tenaga kerja

\begin{tabular}{lcc}
\hline \multicolumn{1}{c}{ Atribut } & Mean & STDev \\
\hline Upah dan gaji & & 0,000 \\
Pendidikan & 2,60 & 0,548 \\
Keterampilan / pelatihan & 2,40 & 0,548 \\
Ketersediaan tenaga kerja & 3,00 & 0,000 \\
Daya tawar tenaga kerja & 2,40 & 0,548 \\
\hline
\end{tabular}

Sumber : Data Penelitian (2017)

\section{Faktor-faktor yang berkontribusi terhadap kemajuan industri filet patin Indonesia}

Sebagian besar responden mengindikasikan bahwa faktor iklim usaha yang baik dan lingkungan usaha yang kondusif sangat tinggi kontribusinya teradap kemajuan industri filet patin dalam negeri yang ditunjukan oleh skor data 4,20. Dengan standar deviasi yang rendah menunjukan bahwa responden setuju dengan kondisi tersebut. Sementara untuk faktor-faktor kedekatan dengan ibukota, bahan baku, akses tol, pelabuhan dan bandara, tenaga kerja yang melimpah merupakan faktor yang tingkat kontribusinya sedang terhadap kemajuan industri filet patin dalam negeri. Penyimpangan standar relatif rendah yang mengindikasikan bahwa sebagian besar responden sepakat.

Tabel 10 Faktor kontribusi

\begin{tabular}{lll}
\hline \multicolumn{1}{c}{ Atribut } & Mean & STDev \\
\hline Dekat dengan ibu kota & 3,60 & 1,140 \\
Dekat dengan sumberdaya bahan baku & 3,60 & 0,894 \\
Dekat dengan akses tol & 3,40 & 0,894 \\
Dekat dengan pelabuhan dan bandar udara & 3,40 & 0,894 \\
Tenaga kerja yang murah dan melimpah & 3,80 & 1,095 \\
Iklim usaha yang baik & 4,20 & 0,837 \\
Lingkungan usaha yang kondusif & 4,20 & 0,837 \\
\hline
\end{tabular}

Sumber : Data Penelitian (2017)

\section{Kebijakan Pemerintah}

Pemerintah memainkan peran penting dalam Model Berlian Porter. Porter (1998) berpendapat bahwa pemerintah bertindak sebagai katalisator dan penantang bagi perusahaan untuk meningkatkan aspirasi mereka. Para responden menilai seberapa jauh pemerintah telah mendukung bisnis mereka melalui kebijakannya. 
Tabel 11 menunjukan bahwa kebijakan pemerintah mengenai perlindungan industri komoditas patin dalam negeri dan peraturan industri komoditas patin mendukung berkembangnya industri filet patin dalam negeri sebagaimana ditunjukkan oleh nilai rata-rata masing-masing 4,00. Kebijakan lain yang dipertimbangkan cukup mendukung termasuk kebijakan pemerintah tentang tenaga kerja; Kebijakan pemerintah tentang teknologi; Kebijakan pemerintah tentang infrastruktur; kebijakan pemerintah mengenai stimulus permintaan pasar; kebijakan pemerintah mengenai industri komoditas patin; kebijakan Pemerintah mengenai perpajakan; dan Iklim dan stabilitas politik seperti yang ditunjukkan oleh skor rata-rata 3,60, 3,80, 3,60, 3,60, 3,60, 3,20, dan 3,40.

Tabel 11 Kebijakan pemerintah

\begin{tabular}{lcc}
\hline \multicolumn{1}{c}{ Atribut } & Mean & STDev \\
\hline Kebijakan pemerintah mengenai tenaga kerja & 3,60 & 0,548 \\
Kebijakan pemerintah mengenai teknologi & 3,80 & 0,447 \\
Kebijakan pemerintah mengenai infrastruktur & 3,60 & 0,548 \\
Kebijakan pemerintah mengenai stimulus permintaan pasar & 3,60 & 0,548 \\
Kebijakan pemerintah mengenai industri komoditas patin & 3,60 & 0,548 \\
Kebijakan pemerintah mengenai perlindungan industri komoditas patin & 4,00 & 0,707 \\
dalam negeri & 3,20 & 0,837 \\
Kebijakan pemerintah mengenai perpajakan & 4,00 & 0,707 \\
Kebijakan pemerintah mengenai peraturan industri komoditas patin & 3,40 & 0,548 \\
Iklim dan stabilitas politik & & \\
\hline
\end{tabular}
Sumber : Data Penelitian (2017)

\section{Industri Pendukung}

Penelitian ini juga memberikan gambaran sejauh mana industri pendukung berkontribusi terhadap kemajuan industri filet patin dalam negeri. Dari Tabel 12 menunjukan bahwan pemasok bahan baku $(3,20)$, perusahaan pesaing $(3,00)$, sekolah/perguruan tinggi $(3,00)$ dan lembaga penelitian $(3,00)$ berkontribusi pada tingkat sedang terhadap kemajuan industri filet patin dalam negeri. Sementara serikat buruh $(2,20)$ perusahaan asuransi $(2,20)$ dan Bank/lembaga keuangan $(2,80)$ berkonstrbusi rendah terhadap kemajuan industri filet patin dalam negeri.

Tabel 12 Industri pendukung

\begin{tabular}{lcc}
\hline \multicolumn{1}{c}{ Atribut } & Mean & STDev \\
\hline Pemasok bahan baku & 3,20 & 1,304 \\
Perusahaan rekanan & 3,00 & 1,225 \\
Serikat buruh & 2,20 & 0,447 \\
Perusahaan asuransi & 2,20 & 0,447 \\
Bank/lembaga keuangan & 2,80 & 0,837 \\
Sekolah / perguruan tinggi & 3,00 & 0,707 \\
Lembagan penelitian & 3,00 & 0,707 \\
\hline
\end{tabular}

Sumber : Data penelitian (2017)

\section{Struktur Pasar}

Tabel 13 menunjukan bahwa persaingan industri filet patin dipasar internasional dengan skor yang moderat 3,40 menunjujak bahwa persaingan dipasar internasional cenderung tinggi namun tidak sampai tinggi karena hanya negara-negara tertentu yang merupakan penghasil ikan patin. pangsa pasar dalam negeri dengan skor yang sedang 3,20 menunjukan bahwa pasar dalam negeri relatif sedang. Persaingan industri dalam negeri dan banyaknya hambatan masuk ke dalam industri filet patin dalam 
negeri dengan skor 2,80 menunjukan bahwa tingkat persaingan dan hambatan dalam industri filet patin dalam negeri relatif rendah. Sementara untuk pemain dalam industri filet patin dalam negeri dengan skor 2,6 menunjukan pemain dalam industri filet patin sedikit. Akses pasar yang sulit dengan skor 2,40 menunjukan bahwa selama ini akses pasar industri filet patin relatif tidak sulit karenaprodusen filet patin sudahmemiliki konsumen masing-masing.

Tabel 13 menunjukan bahwa persaingan industri filet patin dipasar internasional dengan skor yang moderat 3,40 menunjujak bahwa persaingan dipasar internasional cenderung tinggi namun tidak sampai tinggi karena hanya negara-negara tertentu yang merupakan penghasil ikan patin. pangsa pasar dalam negeri dengan skor yang sedang 3,20 menunjukan bahwa pasar dalam negeri relatif sedang. Persaingan industri dalam negeri dan banyaknya hambatan masuk ke dalam industri filet patin dalam negeri dengan skor 2,80 menunjukan bahwa tingkat persaingan dan hambatan dalam industri filet patin dalam negeri relatif rendah. Sementara untuk pemain dalam industri filet patin dalam negeri dengan skor 2,6 menunjukan pemain dalam industri filet patin sedikit. Akses pasar yang sulit dengan skor 2,40 menunjukan bahwa selama ini akses pasar industri filet patin relatif tidak sulit karenaprodusen filet patin sudahmemiliki konsumen masing-masing.

Tabel 13 Struktur pasar

\begin{tabular}{lrr}
\hline \multicolumn{1}{c}{ Atribut } & Mean & STDev \\
\hline Banyak pemain dalam industri pengolahan file patin & 2,60 & 0,894 \\
Pangsa pasar perusahaan dalam negeri & 3,20 & 0,447 \\
Persaingan dengan perusahaan lokal sejenis & 2,80 & 0,837 \\
Persaingan dipasar internasional & 3,40 & 0,894 \\
Banyak hambatan bagi perusahaan baru untuk masuk dalam industri & 2,80 & 0,837 \\
\hline
\end{tabular}

Sumber : Data Penelitian (2017)

\section{Strategi Pemasaran}

Strategi industri filet patin dalam negeri dengan beberapa indikator menunjukan bahwa penerapan startegi pemasaran masih cenderung rendah, seperti pada Tabel 14, menunjukan bahwa strategi terhadap peningkatan konsumen $(2,80)$, kemasan produk $(2,60)$, variasi produk $(2,20)$, iklan $(2,60)$ dan keterlibatan konsumen $(2,20)$ menunjukan nilai yang masih rendah. sementara inovasi dalam pemasaran $(3,20)$ serta penelitian pemasaran $(3,00)$ menunjukan nilai yang sedang.

Tabel 14 Strategi perusahaan

\begin{tabular}{lcc}
\hline \multicolumn{1}{c}{ Atribut } & Mean & STDev \\
& & \\
\hline Inovasi dalam pemasaran & 3,20 & 0,447 \\
Strategi terhadap peningkatan konsumen & 2,80 & 0,837 \\
Penelitian pemasaran & 3,00 & 0,000 \\
Kemasan produk & 2,60 & 0,548 \\
Variasi produk & 2,20 & 0,447 \\
Iklan & 2,60 & 0,548 \\
Keterlibatan konsumen & 2,20 & 0,447 \\
\hline
\end{tabular}

Sumber : Data Penelitian (2017)

\section{KESIMPULAN}

Model Berlian Porter menunjukan bahwa kondisi input dalam industri filet patin Indonesia dalam kondisi yang cukup tersedia. Biaya input cenderung mahal, kondisi permodalan mendukung industri filet patin dalam tingkat yang sedang. Kondisi tenaga kerja dilihat dari upah, pendidikan dan 
keterampilan masih rendah.Kondisi permintaan dan pertumbuhan industri filet patin Indonesia secara umum masih rendah. Permintaan dalam negeri tidak tinggi sementara permintaan luar negeri cenderung rendah.

Industri terkait dan industri pendukung belum mendukung terhadap perkembangan industri filet patin Indonesia. Struktur pasar industri filet patin dalam negeri menunjukan tingkat persaingan yang rendah didalam negeri karena pemain dalam industri filet patin tidak banyak. Strategi perusahaan dalam pemasaran belum dilakukan secara optimal terlihat dari rendahnya inovasi dan strategi pemasaran yang dilakukan industri filet patin dalam negeri.Pemerintah dengan kebijakankebijakannya sangat berperan dalam upaya meningkatkan kemajuan industri filet patin dalam negeri. Peluang terhadap perkembangan industri filet patin sangat besar mengingat peran dan perhatian pemerintah cukup besar dengan melakukan berbagai upaya pengembangan komoditas patin dari hulu ke hilir.

\section{DAFTAR PUSTAKA}

Natalia, Deasi, Nurozy. 2012. Kinerja Daya Saing Produk Perikanan Indonesiadi Pasar Global. Buletin Ilmiah Litbang Perdagangan.6(1).

[KKP] Kementerian Kelautan dan Perikanan Pusat Data Statistik dan Informasi. 2015. Analisis Data Pokok Kelautan dan Perikanan. Jakarta (ID): KKP.

[KKP] Kementerian Kelautan dan Perikanan. 2014. Lampiran Keputusan Direktur Jenderal Perikanan Budidaya Nomor 21/KEP-DJPB/2014 tentang Rencana Strategis Direktorat Jenderal Perikanan Budidaya Tahun 2010-2014. Jakarta (ID): KKP.

Ramadhan A, Suwandi R, Trilaksani W. 2016. Competitiveness Strategies of Indonesia Pangasius filet. Indonesian Journal of Business and Entrepreneurship. 2(2).

[SEAFDEC] Southeast Asian Fisheries Development Center. Fishery Statistical Bulletin of Southeast Asia. 2014. Bangkok (TH): SEAFDEC.

Suryaningrum, D. 2008. Ikan Patin: Peluang Ekspor, Penanganan Pascapanen, dan Diversifikasi Produk Olahannya. Jurnal Squalen. 1(3). 
Lampiran Model berlian porter industri filet patin Indonesia

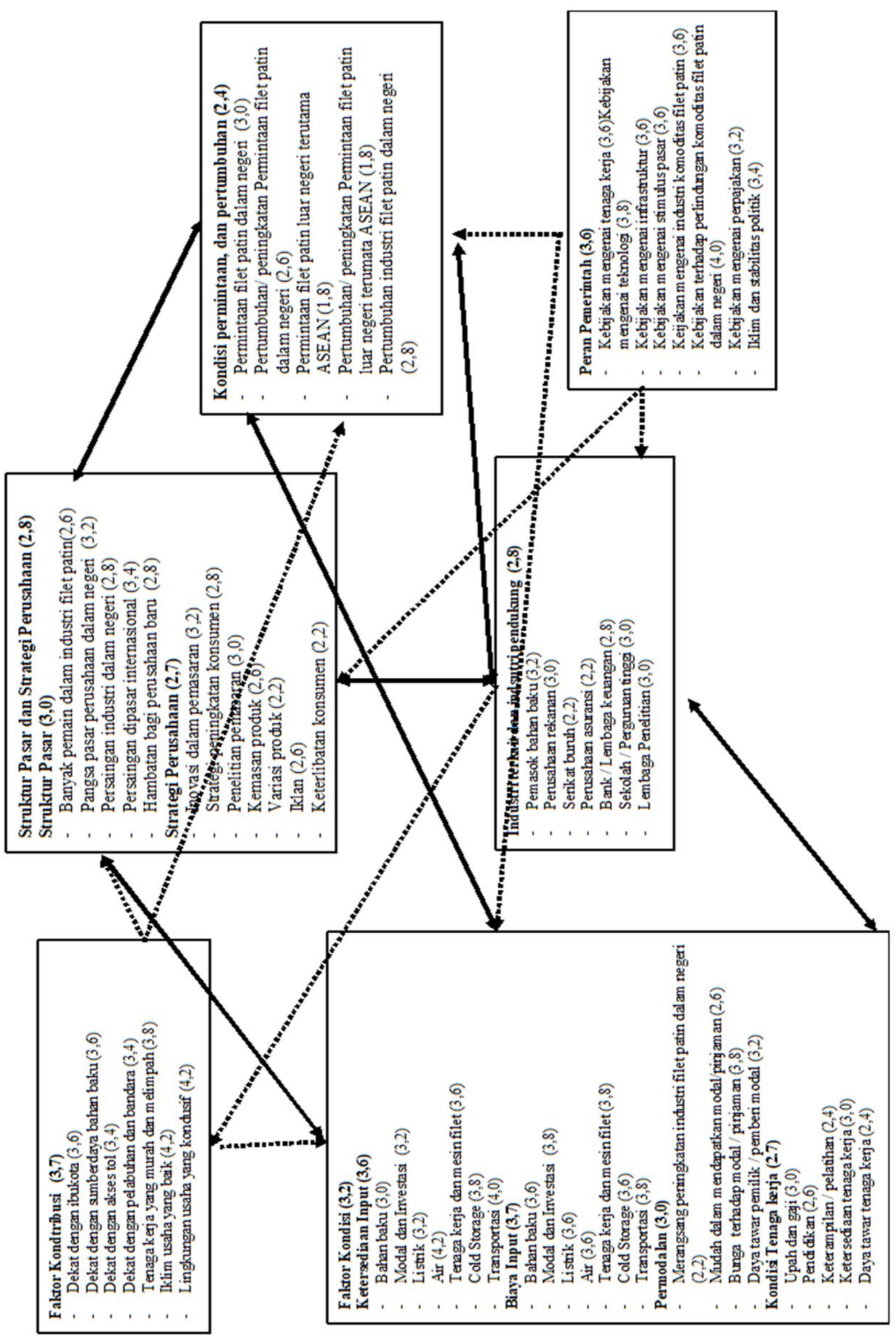

